\title{
Analysis and comment
}

\author{
Public health
}

\section{Blowing smoke: British American Tobacco's air filtration scheme}

Nadine Rae Leavell, Monique E Muggli, Richard D Hurt, James Repace

As Westminster MPs prepare for a free vote on a complete smoking ban in public places, researchers question the efficacy of a technique meant to clear the air of tobacco smoke-heavily promoted by tobacco companies as an alternative to legislation

The health benefits of smoke-free public places are well proved. ${ }^{1-3}$ Nevertheless, the tobacco industry has attempted to create public doubt about and refute the scientific evidence on the adverse health consequences of exposure to environmental tobacco smoke. ${ }^{4-6}$ Furthermore, the industry has promoted the accommodation of smokers and non-smokers by separate seating, ventilation, and air filtration. ${ }^{78}$ None of these proposed solutions, which the UK government promoted in the 1999 Public Places Charter on Smoking, provides adequate protection. We therefore urge the government to pass comprehensive smoke-free workplace and public places laws similar to those already existing in several countries.

\section{Current measures to reduce exposure}

In 1998, the UK Department of Health issued a white paper called Smoking Kills, ${ }^{9}$ which suggested initiatives to address smoking in the workplace and public places through a voluntary and self regulatory Public Places Charter on Smoking. The charter, proposed by the hospitality industry and launched in 1999 by the minister for public health, requires pubs and restaurants that sign up to voluntarily implement several principles including the accommodation of smokers and non-smokers by separate seating, ventilation, and air filtration and to display five specific signs at the entrance showing compliance with these measurements (see bmj.com). The designated policy options are

- Smoking not allowed in public areas

- Smoking allowed in public areas

- Smoking allowed only in designated smoking areas

- Ventilation meets standard; smoking allowed

- Ventilation meets standard; smoking allowed in designated areas.

The charter was promoted and financially supported by members of the tobacco industry. ${ }^{10}$

Although the minister of public health promoted the charter as a step in the right direction, it has been heavily criticised for not being strong enough to create smoke-free public places. ${ }^{11}{ }^{12}$ Its proposed ventilation

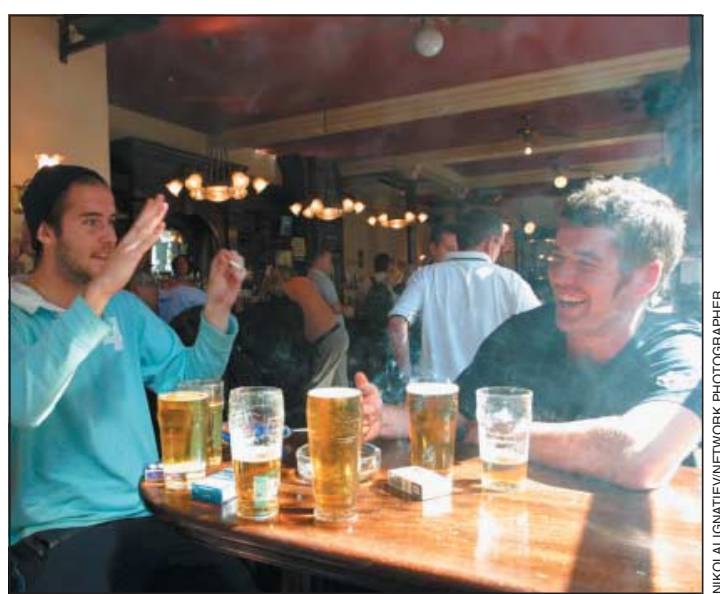

Secondhand smoke is a big hazard for bar workers

standard to control environmental tobacco smoke actually violates the UK 24 hour air quality standard for particulate matter $\left(\mathrm{PM}_{10}\right)$ for workers by a factor of three for a pub at full occupancy and with the prevalence of smoking specified in the charter. ${ }^{13}$ In addition, research has shown that separate smoking sections do not protect people in non-smoking sections from the harmful constituents in environmental tobacco smoke, a conclusion first made 20 years ago by the US Surgeon General. ${ }^{14}$

\section{Industry approach to smoking restrictions}

The motivation behind the tobacco industry's promotion of ventilation and opposition to legislated smoking restrictions seems clear: smoke-free pubs and restaurants reduce the prevalence of smoking. Smokefree workplace laws are associated with reduced consumption by continuing smokers, increased likelihood that a smoker will stop altogether, and a $£ 310 \mathrm{~m}$

References w1-w30 and images of the charter signs are on bmj.com.
Mayo Clinic

Nicotine Research

Program,

Rochester, $\mathrm{MN}$

55905, USA

Nadine Rae Leavell subcontracted

researcher

Monique E Muggli subcontracted researcher

Nicotine

Dependence

Center, Mayo

Clinic, 200 First

Street, SW,

Rochester, MN

55905, USA

Richard D Hurt

director

Tufts University School of Medicine, Boston, USA

James Repace visiting assistant clinical professor

Correspondence to: R D Hurt rhurt@mayo.edu

BMJ 2006;332:227-9 
( $\$ 544 \mathrm{~m} ; € 451 \mathrm{~m})$ annual loss to the tobacco industry. ${ }^{15}$ Recent data from Ireland show that since March 2004, when the smoke-free workplace law was implemented, smoking prevalence fell by $8.6 \%$ to an all time low of $23.3 \%$ in March 2005, although recent trends show an increase to $24 \%$ in October $2005 .^{16}$

Newly released internal corporate documents from British American Tobacco (BAT) show that despite internal acknowledgment that ventilation and air filtration were ineffective at removing environmental tobacco smoke, BAT has extensively promoted these technologies to the hospitality industry since the mid1990s. Documents also show that BAT's strategies to promote these initiatives worldwide were seen internally as viable solutions to circumvent smoking restrictions and to gain global marketing opportunities.

In 1993, ventilation, heating, and lighting manufacturer Colt International gave BAT an air filtration unit to evaluate the system's ability to remove particulate matter, the constituent that gives tobacco smoke a visible presence and odour. BAT determined that the unit was only $34 \%$ efficient at removing particulate matter from cigarette smoke. ${ }^{\mathrm{w} 1 \mathrm{w} 2}$ It reported that the unit did little to remove harmful gas phase smoke constituents including carbon monoxide and volatile organic compounds, but that it significantly reduced "haze, tobacco-smoke aroma and total perceived smoke" ${ }^{\text {"w1 }}$-in other words, particulate matter that could be seen and smelt.

Despite this evidence, BAT concluded that the air filtration unit "was a cost-effective mechanism for removing ETS [environmental tobacco smoke] ... would prove a useful device to incorporate into specific environments where BAT might want to ... gain commercial advantages over its competitors, ${ }^{, w 1}$ and should result in "direct benefits in terms of ... brand (or corporate) awareness and image transfer." ${ }^{\text {"3: }}$ BAT scientist Nigel Warren also stated that the company's interest in air filtration was primarily, "To negate the need for indoor smoking bans around the world, particularly when we can provide pre- and post-filter air quality studies showing substantial air quality improvements." w4

By 1995, BAT had installed Colt air filtration units worldwide. ${ }^{w 5-w 7}$ In one such project, BAT installed the Colt unit at a Brussels airport lounge and branded it throughout with signage, colours, and merchandising items for Barclay cigarettes. ${ }^{\text {w8 }}$ Although it knew that the filtration unit was inadequate, BAT insisted on beginning installation so as not to lose out to competition while waiting for Colt to develop alternative technology. ${ }^{\text {w9-w11 }}$ A memo from Nigel Warren noted that air filtration, if nothing else, could be used to market BAT's products. ${ }^{\mathrm{w} 11}$

BAT targeted the hospitality industry by pushing a so-called "smoker resocialisation" initiative, ${ }^{\mathrm{w} 12}$ which aimed to portray smoking in a "more positive and stylish context" ${ }^{{ }^{\prime 13} 13}$ and to lobby against smoke-free public places. ${ }^{w / 14}$ A memo in February 1996 from Nigel Warren summarises BAT's approach to hospitality managers:

When entering into deals with restaurant/club owners we try to first convince them of the filters capability by demonstrating a "mini" unit which we fill with smoke, switch on, and watch the smoke disappear in a few seconds-an attention grabber. We point out that by imposing a smoking ban in their outlet they may suffer a loss of (smoking) customers and maybe their non-smoking friends too. By introducing filtration systems (at their or our own expense) smoking and non-smoking customers can more easily socialize in the better quality air-indeed such systems may help to increase the number of customers overall. The "penalty" that the restaurant owner may have to bear could be exclusive trade marketing for our brands. Essentially everyone benefits!!"15

Although BAT's board of directors was not convinced of the effectiveness of air filtration units, ${ }^{\mathrm{w} 16-\mathrm{w} 18}$ the Colt units continued to be installed at locations worldwide ${ }^{w 19}$ w20 even in the face of failed performance. ${ }^{\mathrm{w} 21}$

\section{Latest developments}

In 1997 Corporate Responsibility Consulting ${ }^{\text {w22 }}$ created AIR (Atmosphere Improve Results), an indoor air quality consultancy company to "identify and promote practical techniques to resolve the public smoking issue," such as ventilation solutions, in line with the 1999 charter. ${ }^{\text {w23 }}$ AIR is funded by the hospitality and tobacco industries. ${ }^{24}$ An internal BAT memo dated May 2000 reports that AIR was used to "resolve the [environmental tobacco smoke] issue, rather than construct a short-term PR [public relations] and lobbying defence against regulations."' ${ }^{25}$

The document further reports: "To get this level of coverage was beyond the resources of a conventional PR or advertising campaign especially if the source of the campaign was seen to be outside the industry itself." Corporate Responsibility Consulting contacted the leading trade associations and offered them the opportunity to deliver a solution to the problem of environmental tobacco smoke using the resources of the tobacco industry but with their own leadership. ${ }^{\text {.25 }} \mathrm{It}$ aimed to sign up half of the desired 56000 pubs and restaurants to the charter within nine months of its introduction, with a budget of $£ 7930000^{\mathrm{w} 26}$

In June 2000, BAT undertook a joint effort with Corporate Responsibility Consulting to install "smoking tables," originally designed and manufactured by Colt, ${ }^{\mathrm{w} 27}$ in a bar at Birmingham International Airport. These tables suck tobacco smoke down through a filter and recirculate the partially filtered smoke out into the room again. Even if the technology was improved from that in the 1990 filtration units, the tables would be ineffective because isolation of the source or the worker are the only control measures that yield air quality that is safe to breathe. ${ }^{\text {w28 }}$ Again, BAT scientist Nigel Warren commented on the possible perceived effectiveness of these units:

When the tables were switched on and demonstrated, there was obvious amusement caused from the visual impression of smoke disappearing down through the middle of the table and into the filter box. We took this as a very effective perceived solution to the "problems" of smoking in public.".29

Warren also noted: "Until yesterday, this airport had a complete no smoking policy! ... It was a delight to be seen removing the large, red lettered, 'do not smoke here' sign.” ${ }^{29}$ In line with BAT's public relations strategy to be seen as solely accommodating smokers and non-smokers through the use of filtration and ventilation methods, any news release was to use "caution" stating that, "[We] don't want to imply that BAT's goal is to try to overturn smoking bans."w30 


\section{Summary points}

Ventilation and air filtration are ineffective at removing environmental tobacco smoke

Despite this knowledge, BAT extensively promoted these technologies to the hospitality industry

Internal documents show such strategies were viewed as viable solutions to circumvent smoking restrictions and gain global marketing opportunities

A total ban on smoking in public places is the only way to protect all employees from environmental tobacco smoke

\section{New legislation}

In November 2004, the UK government published another white paper, which proposes to end smoking in most workplaces and public places but also proposes exemptions for private clubs and pubs that do not serve food. ${ }^{17}$ This exemption was included despite the fact that the government's scientific committee on tobacco and health advised that bar workers are particularly at risk from secondhand smoke. ${ }^{18}$ According to government estimates, these exemptions would leave $10-30 \%$ of pubs free to choose their own smoking status, and pubs that serve food could stop doing so in order to allow smoking.

The public health community should reject the 2004 white paper's proposal for exemptions to provide smoke-free workplaces for only some workers in the United Kingdom. Without a comprehensive smokefree workplace law, the tobacco and hospitality industries can continue to mislead the public about the hazards of exposure to environmental tobacco smoke by promoting separate seating, ventilation, and air filtration as viable options to smoking bans. This will do nothing to reduce the risk of lung cancer among employees. ${ }^{2}$ Furthermore, people of lower socioeconomic status are more likely to live near pubs and clubs that are exempt from being smoke-free. ${ }^{19}$ All workers deserve to work in smoke-free environments, the United Kingdom should follow the lead of countries such as Bhutan, Cuba, Ireland, Italy, Malta, New Zealand, and Norway in legislating for a total ban on smoking in public places.

Contributors and sources: This article is based on hand searches of internal corporate documents from BAT held in depositories in Minnesota and Guildford set up as a result of litigation against tobacco companies, and documents from online databases of tobacco documents (www.tobacco documents.org) searched between March 2004 and October 2004. NRL has served as researcher, indexer, and project manager for several document-based initiatives within the public health community. Her areas of expertise include information management, cigarette design, and the tobacco industry's advertising and marketing techniques aimed at youth, women, and minority populations. JR is a secondhand smoke consultant who has published extensively on the hazard, exposure, dose, risk, and control of secondhand smoke. He is a former senior policy analyst and scientist with the US Environmental Protection Agency. MEM is a consultant for health groups internationally. She has had extensive experience with researching tobacco industry documents. RDH is an internationally recognized expert on tobacco and author or coauthor of over 150 scientific publications.

Funding: National Institutes for Health grant R01 CA90791.

Competing interests: None declared.

1 Repace JL. Respirable particles and carcinogens in the air of Delaware hospitality venues before and after a smoking ban.J Occup Environ Med 2004;46:887-905.

2 Siegel M. Involuntary smoking in the restaurant workplace. A review of employee exposure and health effects. JAMA 1993;270:490-3.

3 Eisner MD, Smith AK, Blanc PD. Bartenders' respiratory health after establishment of smoke-free bars and taverns. JAMA 1998;280:1909-14.

Barnoya J, Glantz SA. Tobacco industry success in preventing regulation of secondhand smoke in Latin America: the Latin project. Tobacco Control 2002;11:305-14

5 Barnoya J, Glantz SA. The tobacco industry's worldwide ETS consultants project: European and Asian components. Eur J Public Health 2005 Aug 2 [Epub ahead of print].

6 Muggli ME, Hurt RD, Blanke DD. Science for hire: a tobacco industry strategy to influence public opinion on secondhand smoke. Nicotine Tobacco Res 2003;5:303-14.

7 Drope J, Bialous SA, Glantz SA. Tobacco industry efforts to present venDrope J, Bialous SA, Glantz SA. Tobacco industry efforts to present ven-
tilation as an alternative to smoke-free environments in North America. tilation as an alternative to smoke-free
Tobacco Control 2004;13(suppl 1):41-7.

8 Linehan K, Fuller CL. Presentation to the board of directors, June 24, 1992.British American Tobacco. Bates No 2047916000/6013. www.legacy. library.ucsf.edu $/ \mathrm{cgi} /$ getdoc?tid $=$ kgr52e00\&fmt $=$ pdf\&.ref $=$ results (accessed 10 Jan 2006).

9 Department of Health. Smoking kills: a white paper on tobacco. London: DoH, 1998.

10 British American Tobacco Company. The UK's public places charter on smoking. www.bat.com/oneweb/sites/uk_3mnfen.nsf/0/9753a824246f 54d480256bf40001988e? OpenDocument (accessed 10 Jan 2006).

11 McKee M, Hogan H, Gilmore A. Why we need to ban smoking in public places now.J Public Health 2004;26:325-6.

places now.J Public Health 2004;26:325-6.
12 British Medical Association. Smokefree workplaces and public places. British Medical Associn:

London: BMA, 2004.
Repace JL. A killer on the loose. An action on smoking and health special investigation into the threat of passive smoking in the UK workforce. London: Action on Smoking and Health, 2003. www.repace.com/pdf/killer1.pdf (accessed 10 Jan 2006).

14 Department of Health and Human Services. The health consequences of involuntary smoking: a report of the Surgeon General. Washington, DC: DHHS, 1986. (Publication No (CDC) 87-8398.)

15 Fichtenberg C, Glantz SA. Effect of smoke-free workplaces on smoking behaviour: systematic review. BMJ 2002;325:188-91.

16 Ireland Office of Tobacco Control. Current trends in cigarette smoking. Ireland Office of Tobacco Control. Current trends in
www.otc.ie/research_reports.asp (accessed 17 Dec 2005).

17 Department of Health. Choosing health: making health choices easier. London: DoH, 2004 .

18 Action on Smoking and Health. Smoking in workplaces and public places. London: ASH, 2004. www.ash.org.uk/html/factsheets/html/ fact14.html\#_edn8 (accessed 11 Jan 2006).

19 Woodall A, Sandbach E, Woodward C, Aveyard P, Merrington G. The partial smoking ban in licensed establishments and health inequalities in England: modelling study. BMJ 2005;331:488-9.

(Accepted 6 January 2006)

\section{Endpiece}

\section{The tortures that result from high living}

Why should I mention the other innumerable diseases, the tortures that result from high living? Men used to be free from such ills, because they had not yet slackened their strength by indulgence, because they had control over themselves, and supplied their own needs. They toughened their bodies by work and real toil, tiring themselves out by running or hunting or tilling the earth. They were refreshed by food in which only a hungry man could take pleasure. Hence there was no need for all our mighty medical paraphernalia, for so many instruments and pill-boxes. For plain reasons they enjoyed plain health; it took elaborate courses to produce elaborate diseases. Mark the number of things - all to pass down a single throat-that luxury mixes together, after ravaging land and sea. So many different dishes must surely disagree; they are bolted with difficulty and are digested with difficulty, each jostling against each other.

Seneca (5 BC-AD 65), Epistles 95:18-9

Submitted by Jeremy Hugh Baron,

honorary professorial lecturer,

Mount Sinai School of Medicine, New York 